This item was submitted to Loughborough's Research Repository by the author.

Items in Figshare are protected by copyright, with all rights reserved, unless otherwise indicated.

\title{
A study of the relationship between exit, voice, loyalty and neglect and commitment in India
}

PLEASE CITE THE PUBLISHED VERSION

http://dx.doi.org/10.1177/0018726709348932

PUBLISHER

Sage / @ The authors

VERSION

AM (Accepted Manuscript)

LICENCE

CC BY-NC-ND 4.0

REPOSITORY RECORD

Mellahi, Kamel, Pawan S. Budhwar, and Baibing Li. 2019. "A Study of the Relationship Between Exit, Voice, Loyalty and Neglect and Commitment in India”. figshare. https://hdl.handle.net/2134/14648. 
This item was submitted to Loughborough's Institutional Repository (https://dspace.lboro.ac.uk/) by the author and is made available under the following Creative Commons Licence conditions.

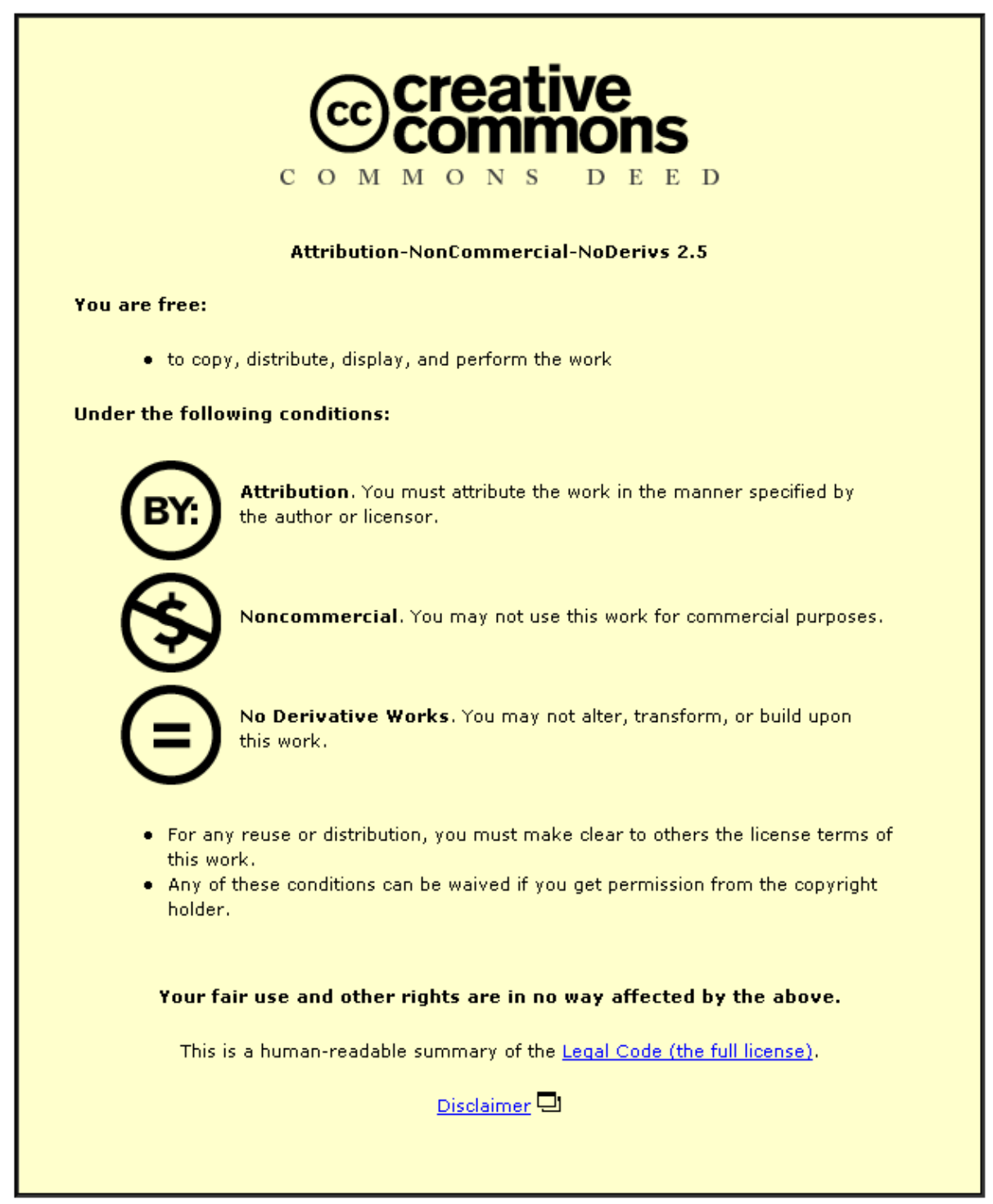

For the full text of this licence, please go to: http://creativecommons.org/licenses/by-nc-nd/2.5/ 


\title{
A Study of the Relationship between Exit, Voice, Loyalty and
}

\section{Neglect and Commitment in India}

\author{
Kamel Mellahi, Loughborough U \\ Pawan Budhwar, Aston, U \\ \&
}

\section{Li Baibing, Loughborough U}

\begin{abstract}
Drawing on exit, voice, loyalty and neglect (EVLN) literature, this study examines direct and interactive associations between organizational-level commitment and team-level commitment and the use of EVLN by managers in India. The study is based on a survey of 200 managers and supervisors from seven Indian firms. The findings on the use of voice are consistent with the past research in western countries, but challenge the prevailing assumption about the use of voice in high power distance societies. The results also indicate that team-level commitment moderates the association between organizational level-commitment and the use of EVLN.
\end{abstract}




\section{Introduction}

Ever since Albert O Hirschman (1970) asserted that individuals respond to dissatisfaction with organizations by choosing from three possible conducts: exit, voice and loyalty, a large body of research has used his framework to explain the attitudes and behavior of employees towards adverse organizational circumstances including grievances (Lewin \& Boroff, 1996; Freeman \& Medoff, 1984), organizational cynicism (Naus, Iterson \& Roe, 2007) and dissatisfaction (Farrell, 1983; Withey \& Cooper, 1989). Rusbelt et al. (1982) added neglect to exit, voice and loyalty to distinguish between loyalty which refers to behaviors that aim to help the organization such as being patient and trusting management to do the right thing to rectify the problem, and neglect which refers to "lax and disregardful behavior among workers” (Farrell 1983: 598). Rusbult et al. (1998: 601) noted that employees neglect their organization when they passively allow "conditions to moderate through reduced interest or effort, chronic lateness or absences”.

Much of this body of research, however, focuses on Western developed economies. The primary aim of this paper is to expand this body of knowledge to non-western countries. Specifically, we build on an extant research on the exit, voice, loyalty and neglect (EVLN) framework (Hirschman, 1970; Farrell, 1983; Naus et al., 2007; Rusbult et al., 1982; Rusbult et al., 1988) to examine the association between different forms and foci of commitment and line managers' and supervisory staffs' behavioral intention to exit the organization, voice their concerns, remain loyal or neglect the organization as a response to any objectionable state of affairs in the Indian context. 
This study is significant for two main reasons. First, although empirical research on employees' reaction to adverse organizational circumstances is substantial in western developed countries (Hoffmann, 2005; Hagedoorn et al., 1999; Withey \& Cooper, 1989), empirical investigation on this issue in non-western countries is limited. Further, generalizability of the findings on individuals' responses to dissatisfaction from studies conducted in a western context to a non-western context is certainly questionable due to their socio-cultural and institutional differences. For instance, practices such as the use of voice that "is heavily entrenched in the labour market policies of many advanced and industrialized countries” (Luchak, 2003: 115) may not be so common in the non-western context. We choose India for this study as since liberalizing its economic policies in 1991 its economy has done well and the World Bank forecasts that by 2020, India could become the world's fourth largest economy. However, to date, research involving Indian organizational behavior remains scarce (e.g., Budhwar \& Bhatnagar, 2009).

Second, in addition to extending the literature on EVLN to a new cultural setting, we also aim to refine the association between the use of EVLN and commitment. With some exception (Luchak, 2003), traditionally the link between organizational commitment and EVLN has been studied by examining the link between one type or foci of organizational commitment and use of EVLN (Boroff \& Lewin, 1977). In this study, we contend that focusing on a single type of organizational commitment does not allow researchers to capture the possible impacts different types of commitment have on employees' actions (Johnson et 
al., 2009). To fill this gap, we examine the association between different forms of organizational-level commitment and team-level commitment and EVLN in the Indian set-up.

Theoretical Framework: Different Forms and Foci of Commitment and EVLN

Early studies on the association between commitment and use of EVLN did not differentiate between different types of commitment, and focused on one form of commitment (Hirschman, 1970; Withey \& Cooper, 1989; Rusbult et al., 1988; Lewin \& Boroff, 1996) . Lately, Luchak (2003) examined the association between exit and voice and two forms of commitment to the organization: affective emotional bond and rational calculated bond. This study reports that individuals attached to their organization for affective emotional reason are less likely to use representative $^{1}$ voice and are more likely to use direct voice. In contrast, those attached to the organization for rational calculated reason are more likely to use representative voice. Further, either type of attachment decreases the likelihood of exit. These findings underscore the importance of considering the association between EVLN and different forms of commitment. Thus, in this study, we differentiate between two types of commitment on the bases of commitment. We examine the association between calculative commitment (Kidron, 1978) and more specifically continuance commitment (Meyer \& Allen, 1984) and attitudinal commitment (Meyer \& Allen, 1984; Solinger et al., 2008), and the use of EVLN. Based on Luchak’s (2003) findings, we suggest that the type of attachment to the

\footnotetext{
${ }^{1}$ Direct voice refers to direct two-way communication to bring about change. Representative voice refers to communication through a third party such as unions (Luchak, 2003).
} 
organization has an impact on individuals' response to dissatisfaction. This differentiation between the two forms of commitment is warranted for at least two reasons. First, this approach of examining different types of commitment and employees' reaction has received support in non-western countries (see Vandenberghe et al., 2001) and has been empirically supported in different parts of the world including Europe (Brockner et al., 2001), Asia (Shaffer et al., 2000) and India (Kwantes, 2003). Second, a number of studies in non-western countries provide evidence to suggest significant and different associations between the different forms of commitment and employees' decision to remain or leave the organization (e.g., Kwantes, 2003 in India; and Chen \& Francesco, 2000 in China).

In addition to differentiating between different forms of organizational-level commitments, Johnson et al. (2009) argue that scholars should include different foci of commitment such as team-level commitment. Thus, in this study we examined the impact of commitment to the team on EVLN. Similar to organizations, teams develop goals and values that members of teams may attach to, and identify with. The differentiation between organizational-level commitment and team-level commitment is warranted in the study of EVLN because it is likely that an employee may be committed to the organization, yet feels unattached and unhappy with their team and vice versa (Bishop \& Scott 2000; Bishop et al., 2000; Johnson et al., 2009). Furthermore, by incorporating team-level commitment we are able to examine the interactive effects of different foci of commitment on ELVN. 


\section{Hypotheses Development}

\section{Organizational Commitment and EVLN}

For Hirschman (1970), loyalty - “commitment" hereafter ${ }^{\mathrm{i}}$ is made-up of factors that tie an individual to his or her organization and impact employees' choices. The primary factor influencing employees is the degree of dependence on the organization such as availability of an alternate employment (Kanter, 1968). Although Hirschman did not define in precise terms what he meant by his economic-cost based commitment, it is close to the concept of Kidron's (1978) calculative commitment and Meyer \& Allen’s (1984) concept of continuance commitment. Past research on these concepts of commitment suggests that when employees have no viable or desirable alternative outside their organization, or when the cost of exit far out-weighs the benefits of staying, employees are less likely to leave the organization (Kidron, 1978; Cappelli \& Chauvin, 1991; Chen \& Francisco, 2000). Hirschman (1970:77) argues that calculative commitment “makes exit less likely”. Thus, we propose that employees who are committed to their organization because of lack of better options outside the organization are less likely to exit.

Similarly, but for different reasons, we suggest that employees who have an attitudinal commitment towards the organization are less likely to exit. Attitudinal commitment refers to "the relative strength of an individual's identification with and involvement in a particular organization” (Mowday, Porter \& Steers, 1982: 27). Extant research consistently shows that individuals that have an emotional attachment to the organization are less likely to exit because of a sense of obligation towards the organization (Meyer \& Allen 1997: 11), and the desire to 
stay and help the organization improve (Luchak, 2003; Boroff \& Lewin 1997). Thus, we propose that:

H1a: Calculative commitment is negatively associated with exit.

H1b: Attitudinal commitment is negatively associated with exit.

Extant research on the use and consequences of voice provide conflicting results. On the one hand, a number of scholars (Zhou \& George, 2001), implicitly or explicitly, argue that the use of voice by employees contributes positively to employees' well-being and organizational effectiveness. On the other hand, scholars that used filing grievances as a proxy for voice found that use of voice has negative consequences on those that use it (Oslon-Buchanan, 1996; Cappelli \& Chauvin, 1991; Boroff \& Lewin, 1997) because “employers tend to exercise retribution against grievance filers” (Lewin \& Peterson, 1999: 554) and as a result individuals are unlikely to voice their concerns (Boroff \& Lewin 1977: 60) and tend to stay quiet and suffer in silence when dissatisfied with their organization.

Given the high power distance (Budhwar \& Sparrow, 2002) and strong collectivist tendencies (Kwantes, 2003) in India, one would expect employees to seek to maintain a harmonious working relationship with their supervisors. Speaking up against one's supervisor may damage the relationship between the employees and their supervisor (Saini \& Budhwar, 2008), and therefore employees are less likely to use direct upward communication such us raising their voice to discontent (Erdogan \& Liden, 2006). Other factors that restrain individuals from speaking up in high power distance cultures such as India include respect for authority (Kakar, 
1971; Sparrow \& Budhwar, 1997; Brockner et al. 2001), and unwillingness of managers to share decision making power with their subordinates (Budhwar \& Sparrow, 2002). This highlights the interplay of the Indian value system which has its bases in the traditional caste system, joint-family system, community and religious groupings, rules of paternalism, and authoritarian culture (Gopalan \& Rivera 1997; Sinha \& Sinha 1990). Taken the above together, one would expect managers in India to respond less favourably to the use of voice by subordinates (Saini \& Budhwar, 2008). Therefore, we expect that individuals with high calculative commitment are less likely to go against the cultural grains and use voice and as a consequence risk possible retribution from superiors.

However, notwithstanding the potential personal cost and strong cultural barriers against speaking up in India, we put forward a tentative proposition that attitudinal commitment makes individual more likely to use voice. In a collectivist culture such as India, employees may put the interest of the organization ahead of theirs (Ramamoorthy \& Flood, 2002; Budhwar et al., 2008). Therefore, employees with strong attitudinal attachment to the organization may be willing to take the risk of speaking up and perhaps violate the cultural norms of respecting authority to stop the organization from deteriorating. Thus, we tentatively propose that:

H2a: Calculative commitment is negatively associated with voice.

H2b: Attitudinal commitment is positively associated with voice. 
Consistent with past research, we posit that the form of commitment influences employees' choices between loyalty and neglect. We argue that although employees with high calculative commitment may not exit or use voice, they are likely to choose neglect rather than loyalty. Shore and Wayne (1993: 779) argue that "employees who are bound by their economic exchange are least likely to be good citizens”. Similarly, Luchak (2003) notes that when employees “are staying with an organization essentially because they feel that they have no other choice on the matter, they are not expected to have a particularly strong desire to contribute to it”. Therefore, it is reasonable to expect individuals with high calculative commitment to neglect the organization and less likely to be loyal to it. Thus, we propose that:

H3a: Calculative commitment is positively associated with neglect.

H3b: Calculative commitment is negatively associated with loyalty.

In contrast to calculative commitment, past research reports a positive relationship between attitudinal commitment and loyalty (Organ, 1988; Hagedoorn et al., 1999). This proposition is predicated on the assumption that employees that have an emotional attachment to the organization are less likely to neglect the organization and allow the situation to worsen. Research on related subjects in Eastern cultures reports similar findings. For instance, research suggests that attachment to, and identification with the organization increases the likelihood of loyalty and decreases the likelihood of neglect in Indonesia (Thomas \& Pekerti, 2003) and China (Chen \& Fransisco, 2000). Thus, we propose that:

H4a: Attitudinal commitment is positively associated with loyalty.

H4b: Attitudinal commitment is negatively associated with neglect. 


\section{Team Commitment and EVLN}

As noted above, team commitment not only moderates the effects of organizational level commitment but also may exert different direct influences on employees’ outcomes. Research in Eastern societies found that employees relate strongly to people whom they work with more than to their organizations (Hui \& Rousseau, 2004). Triandis (1994) highlights that in collective cultures employees put a premium on team harmony and assisting the group. Similarly, Early (1989) argues that in collectivist cultures, employees have a strong attachment to the group and go beyond the call of duty to help their groups. In India, Saini \& Budhwar (2008) found that Indian employees have a tendency to develop personalized relationships with their groups. Thus, we posit that team commitment is associated with behavior that impacts employees' relationship with their teams ${ }^{\text {ii }}$. Recognizing the social and emotional attachment to teams, one would expect employees with high team commitment to be active and constructive members of their team and therefore not to neglect their organization in the face of dissatisfaction with the organization. Further, employees who care about their teams may not quit their organization when faced with an unpleasant situation. Based on such assumptions we propose that:

H5: Team commitment is a) negatively associated with exit; b) negatively associated with neglect; and c) positively associated with loyalty.

Interaction between Organizational-Level Commitment and Team-Level

\section{Commitment}


An emerging body of research suggests potential, yet unexplored, interactive effects of different foci of loyalty -i.e. organizational-level commitment and team-level commitment and employee outcomes (Johnson et al., 2009; Hunt \& Morgan, 1994; Redman \& Snape, 2005; Bishop, Scott and Csino, 1997). Becker (1992) argues that organizational commitment and team commitment, rather than organizational or team commitment per se, influences employees’ outcomes. Johnson et al. (2009) urged researchers to look beyond the simple direct main effects "in the investigation of the consequences of commitment" and examine the interactive effects of different foci of commitment. Notwithstanding the lack of research on the interactive effects of commitment to the organization and commitment to the team on EVLN factors, it is reasonable to expect that high level of team commitment accentuates the above hypothesized positive association between attitudinal commitment and loyalty and the negative association between attitudinal commitment and exit and neglect (Costa, 2003; Becker 1992). This assertion is predicated on the assumption that individuals who are highly committed to both foci have greater reasons to behave constructively which should translate into a greater propensity to stay loyal to the organization rather than exit or neglect the organization (Johnson et al., 2009). Furthermore, team commitment could potentially moderate the effects of calculative commitment on some of the EVLN factors. For instance, the strain evoked by management malpractice could be mitigated by the support of team members and satisfaction employees gain from their teams. Thus, we expect that a high level of team commitment strengthens the expected negative association between calculative commitment and exit. However, in contrast to the synergistic effects of the two foci of commitment on exit, we expect that at high levels of calculative 
commitment and team commitment, the two foci of commitments work against each other on their effects on neglect. That is, as far as neglect is concerned, commitment to both foci pulls “employees in different directions” (Johnson et al., 2009). This is because, while high calculative commitment may lead to neglect, high team commitment inhibits employees from neglecting the organization and letting their team down. Therefore, we believe that high team commitment weakens the expected positive association between calculative commitment and neglect.

Although we are able to put forward some tentative propositions for the moderating effects of high team-level commitment on the association between organizational-level commitment and EVLN outcomes, we refrain from so doing at a low-level of team commitment. This is because, in addition to absence of research that could inform us on the direction of these interactions, the interaction between the two foci of commitment at low-level team commitment is too complex to hypothesize at this stage. Therefore, although we empirically test for the moderating effects of the two foci of commitment on EVLN, we restrict our propositions to the direction of the moderation effects at a high level of team commitment. Thus, we propose that:

H6. The level of team commitment moderates the association between attitudinal commitment and EVLN such that at a high level of team commitment, attitudinal commitment has a strong positive association with loyalty and a strong negative associated with exit and neglect.

H7. The level of team commitment moderates the association between calculative commitment and EVLN such that at a high level of team commitment, calculative commitment has a strong negative association with exit and a weak association with neglect. 


\section{Method}

\section{Sample}

We conducted a questionnaire survey to collect the data between June and July 2004. English is a commonly used business language in India; hence the questionnaire was constructed in English. We targeted supervisory and line manager level of employees because they are closer to the research issues and are the best people to report on the same. Given the common problem of low response rate for postal surveys in India, we approached fifteen companies for access prior to sending out the questionnaires. Seven local Indian SMEs agreed to participate in the research; five from manufacturing and two from the service sector. The smallest firm had around 150 employees, and the largest around 500. 30 line and supervisory managers from diverse functions were randomly selected from each participating firm. Questionnaires were distributed by hand by one of the authors after a briefing to respondents about the aims and usefulness of the research project. Along with the questionnaire we also provided an envelope in which we requested the respondents to put the completed questionnaire and put it in a box placed next to their HR department. Although participation in the study was voluntary, given top management support for the research, we obtained a close to $100 \%$ response rate: almost all the questionnaires were returned but few were incomplete and therefore were not used. We received a total of 200 usable responses giving a response rate of $95 \%$. As shown in Table 1, over $54 \%$ of the respondents held managerial positions, the rest held supervisory positions. Over $90 \%$ of them were males. Nearly $50 \%$ of the respondents had higher secondary education and only $6.5 \%$ had university education. 


\section{Variables and Measurement}

\section{Commitment Items}

Attitudinal commitment was measured by a four-item scale adopted from Porter et al. (1974) using a 5-point Likert scale with $1=$ strongly disagree to $5=$ strongly agree (Table 2). Calculative commitment represents the extent to which respondents have a viable alternative employment outside their current organization. This was measured on a 5-point Likert scale with $1=$ strongly disagree to 5 = strongly agree using Lee at al.’s (2001) two item-scale. It must be pointed out that our measure does not capture the high personal sacrifice subdimension of calculative commitment, and our results should be viewed with this limitation in mind. Finally, team commitment was measured by a five-item scale on a 5 -point Likert scale ( $1=$ strongly disagree to $5=$ strongly agree $)$ adopted from Porter et al. (1974). Details of the items along with reliability scores of the scales are provided in table 2.

\section{EVLN Items}

In order to examine the behavioral intention to EVLN, we drew on the well established psychology theories of reasoned action (Ajzen \& Fishbein, 1980; Fishbein \& Ajzen, 1975) and planned behavior (Ajzen, 1991). The core thesis of these theories is that individuals' behaviors are influenced to a large extent by their behavioral intention to perform a given behavior. Although, a number of factors beside intentions determine individuals' actual behaviors, studies on behavioral intentions to hypothetical scenarios are widely used and found very useful in predicting a wide range of behavior including predicting turnover (Prestholdt et al., 1987) and unethical behavior (Randall \& Gibson, 1991; 
Vallerand et al., 1992). Research participants were provided with a hypothetical scenario in which they believed their superior to be incompetent and take managerial actions that could damage the competitive position of the organization.

The EVLN factors were exit (four-item scale), voice (six-item scale), loyalty (four-item scale) and neglect (five-item scale). These items are adopted and amended from Hagedoorn et al. (1999). To test the suitability of these items in the Indian context, we first piloted them with Indian managers and dropped several items that were found not to be compatible with Indian cultural values and norms. Specifically, we dropped Hagedoom et al.’s aggressive voice items which include contending behaviors such as verbal violence (using hostile language, abusive language, etc.). This is because line managers and subordinates are less likely to exhibit aggressive voice in India (Hofstede, 1991; Saini \& Budhwar, 2008).

\section{Control variables}

We controlled for five variables. Turnley \& Feldman (1999) report that tenure is associated with the use of EVLN. Thus, we controlled for tenure measured by the number of years one spent working for the organization. Further, Mellahi \& Guermat (2004) report that young Indian managers behave differently from older managers, thus we controlled for age of the respondents. Further, research shows that men are more likely to use voice than women (Lewin \& Peterson, 1988). Thus, we controlled for gender. While past research has not examined the impact of education on behavior in India, it is reasonable to expect that the level of education would have an influence on individuals' behavior towards 
mismanagement. Therefore, we controlled for the level of education of the respondents. Finally, given the high power distance in the Indian society and the hierarchical structure of Indian organization, we suspect that the position of the individual has an impact on the use of EVLN. Thus, we controlled for position. Respondents were grouped into line managers (position=1) and supervisors (position =0).

\section{Results}

Before testing our hypotheses, we conducted exploratory factor analysis with an orthogonal rotation, varimax on the forms of commitment and EVLN items. The obtained KMO measure for the different bases of commitment is 0.76 , which is considered to be good. To select an appropriate factor analysis model, we used the Kaiser's rule, retaining only those factors whose eigenvalues are greater than unity (Kaiser, 1974). The analysis yielded a three-factor model with the three factors explaining $23.1 \%, 22.5 \%$ and $14.7 \%$ of variance respectively. Furthermore, given that we asked the same respondent to assess both the independent and dependent variables, we used the Harman single-factor test (Podsakoff \& Organ. 1986) to empirically determine the extent to which common method bias was present in our dataset. The results show that common method bias does not appear to be a problem”. 
Factor loadings for the orthogonal rotation factor analysis for three types of commitment are displayed in Table 2. It turned out that only one out of twelve items had a factor loading smaller than 0.45, which therefore was dropped following Stevens (2002: 393-394). In line with the theoretical analysis, the three factors could be interpreted as team commitment (Factor A1), attitudinal commitment (Factor A2), and calculative commitment (Factor A3) respectively. In addition, we computed Cronbach alpha for each of the resultant factors. The Cronbach alpha scores for the three factors are $0.73,0.77$ and 0.73 respectively.

We also performed a factor analysis to investigate the structure of the respondents' response in terms of EVLN. The obtained KMO measure is 0.772. The results of the factor analysis as displayed in Table 3 confirm the emergence of a four-factor model with each factor explaining $20.4 \%, 14.7 \%, 13.4 \%$ and $12.1 \%$ of variance respectively. In line with the theoretical analysis, the four factors could be interpreted as neglect (Factor B1), voice (Factor B2), exit (Factor B3), and loyalty (Factor B4) respectively. Their respective Cronbach alphas are 0.92, 0.66, 0.77 and 0.71 respectively.

\section{INSERT TABLES 3 \& 4 AROUND HERE}

\section{Hypotheses Testing}

First, we performed correlation analysis to investigate the bivariate relationships between a commitment-based factor and an EVLN factor extracted from the previous factor analyses. Taking the control variables into account, partial 
correlation analysis was carried out where correlation coefficients were adjusted for the control variables. The results are displayed in Table 4.

We used multiple hierarchical regression analyses to test our hypotheses. In the first model (Model 1), each EVLN factor was regressed on the five control variables, as well as attitudinal commitment and calculative commitment to capture the direct association between organizational-level commitment and EVLN factors. Next, in Model 2, we added team commitment to test the association between team-level commitment and EVLN factors and see if the organizational-level commitment variables change when controlling for team commitment. Finally, in Model 3, two interactions (i.e. team×attitudinal and team $\times$ calculative), were added to test how team-level commitment moderates the relationships of the organizational-level constructs and the EVLN factors.

The results of our first and second stage regressions (Model 1 and Model 2, see Table 5) show that exit is not significantly associated with calculative commitment or attitudinal commitment, thus hypotheses $\mathrm{H} 1 \mathrm{a}$ and $\mathrm{H} 1 \mathrm{~b}$ are not supported. Furthermore, the results in both Model 1 and Model 2 show that voice is not significantly associated with calculative commitment, thus not supporting H2a. The results reveal that while voice is not significantly associated with attitudinal commitment in Model 1, it turned significant and positive in Model 2, thus supporting H2b. Consistent with our expectations, the results show that neglect has a significant positive association with calculative commitment in Model 1, but the results became insignificant in Model 2. Contrary to our expectations, the results show that loyalty has a significant positive association 
with calculative commitment in both Model 1 and Model 2; thus rejecting H3b. Finally, in line with our expectations, the results show that loyalty has a significant positive association with attitudinal commitment in both Model 1 and Model 2, thus supporting H4a.

The results on the association between team-level commitment and EVLN show that, attachment to the team is negatively associated with neglect, thus supporting H5b. However, the results show that team level commitment is not associated with exit and loyalty, thus not supporting H5a and H5c.

The results of our final regressions (Model 3, Table 5) reveal that team commitment does indeed moderate the relationship between organizational-level commitment and some of the EVLN factors providing partial support for $\mathrm{H} 6$ and H7. Specifically, the results reveal that team commitment moderates the relationship between calculative commitment and exit, attitudinal commitment and voice, and calculative commitment and neglect. No other significant interactions were observed.

To explore the direction of these significant interactions, we plotted the interactions for the three significant interactions following Aiken and West (1991). We set the level of team commitment to be one standard deviation above and below the mean respectively. All control variables are fixed at their means. According to Figure 1, at a high level of team commitment, calculative commitment is positively associated with exit. At a low level of team commitment, calculative commitment is negatively associated with exit. Figure 2 
reveals that at a low level of team commitment, attitudinal commitment has a positive association with voice. However, at a high level of team commitment, the strength of the association between attitudinal commitment and voice diminishes and becomes insignificant. Finally, Figure 3 reveals that at a high level of team commitment, calculative commitment has a negative association with neglect. At a low level of team commitment, however, the direction of the moderation is reversed, i.e. calculative commitment has a positive association with neglect.

\section{INSERT TABLE 5 \& FIGURES 1, 2 \& 3HERE}

\section{Discussion}

This study expands the current literature on EVLN and commitment to a new cultural context. A steady stream of research has examined employees' reaction to dissatisfaction with their organization and how commitment affects their choices to dissatisfaction. Yet, much of this research is carried out in western countries, and as a result, we know very little on how employees react to dissatisfaction in non-western countries such as India. This study aimed to close this gap in our knowledge. Further, this study aimed to broaden both the empirical and theoretical foundations of EVLN research by developing and testing hypotheses on the linkage between different forms and foci of commitment and EVLN in India.

Our findings challenge some of the findings from the extant research carried out in western countries. In contrast to extant research, and contrary to our expectations, the results show that no form of commitment has a direct and 
significant association with the use of exit. This is an interesting finding given that research has consistently shown that individuals who are highly attached to, or who have no viable or desirable alternative outside their organization, are less likely to use exit than individuals with a low attachment to, or who are less dependent on the organization (Meyer \& Allen, 1984). There are two plausible alternative explanations for our result; the first is instrumental and the second is cultural. First, the high growth of the Indian economy during the research period could have enabled employees' mobility between jobs without fear of unemployment (see Budhwar et al., 2006). Ramamoorthy et al.’s (2007: 1999) study shows that Indian employees during the 2003-2004 period reported low tenure intent and a high level of commitment. Second, an alternative explanation could be the fact that in a collectivist culture such as India, individuals subordinate their personal goals for the sake of the organization regardless of their level of attachment to the organization (Ramamoorthy \& Carroll, 1998; Saini \& Budhwar, 2008). Ramamoorthy et al. (2007) note that employees in India are bounded by the social perimeter of their groups (Ramamoorthy \& Flood, 2002) and the relationship between an employee and the organization extends beyond the contractual nature to a mutual moral obligation where employees remain with the organization even if their goals differ. Therefore, individuals' level and form of commitment do not come into play in their decisions to exit the organization.

The results provide support for our tentative assumption that attitudinal commitment is positively associated with the use of voice. This is consistent with the extant research in western countries that shows that employees with high attitudinal commitment are more likely to use voice but challenges the commonly 
held assumption about the use of voice in high power distance cultures. This could be because Indian values are changing (Budhwar et al., 2006) due partly to the increasing influence of western management practices such as empowerment of subordinates. Further, extant research on the use of voice in high power distance societies did not consider or control for the possible impact of commitment. It is reasonable to expect that committed individuals may be more likely to use voice than those who are not. Our results suggest that the level of individuals' attachment to the organizations has a significant impact on the use of voice in organizations. This underscores the importance of controlling for level of attachment to the organization when studying individuals' outcomes in high power distance societies.

The results on the association between calculative commitment and loyalty are counter intuitive. Contrary to our expectations, the results indicate that calculative commitment is positively associated with loyalty and not associated with neglect. One plausible explanation is that individuals who do not have better options outside the organization may stay loyal to the organization out of necessity rather than desire or sense of obligation. We suggest that future research unpacks the concept of loyalty and distinguishes between individuals’ loyalty stemming from desire and obligation to help the organization and necessity because of lack of options outside the organization.

As predicted, the results show that when individuals are highly committed to their teams they are less likely to neglect their organization. A plausible explanation for the result is that individuals who have a high attachment to their teams are less 
likely to let their team down by neglecting the organization through reduction in work efforts or engagement in destructive behavior such as carelessness or sabotage.

The results on the interactive effects between organizational-level commitment and team-level commitment produced intriguing results. First, while one would expect that at a high level of team commitment and calculative commitment individuals would have more at stake if they left the organization, our results indicate that when individuals are committed to both foci, exit is more likely. Further, the results indicate that individuals who are not committed to their team but have a high calculative commitment, are less likely to exit the organization. To shed further light on this perplexing result we conducted a correlation analysis between the two constructs and found that individuals who are committed to both foci are likely to be highly educated. Therefore, one plausible explanation for our results is that educated individuals who are highly committed to their teams and have little viable options outside the organization may leave the organization together to perhaps start a new venture. However, for individuals with low team commitment, the latter option may not be desirable and therefore may not leave the organization. For practitioners, these results suggest that managers should not expect employees with little viable options outside the organization "to put up or shut up”. Our results suggest that individuals with a high team commitment may leave the organization even if their options outside the organization are less attractive. 
The findings indicate that individuals who have a low attachment to their team but have a high attachment to their organization are more likely to use voice. However, individuals who are attached to both team and organization are less inclined to use voice. One plausible explanation for these findings is that individuals who are attached to their team are able, or perhaps prefer, to vent their frustration with the organization at the team level. In contrast, individuals who are not attached to their team have little option but to raise their voice at the organizational level. These results have implications for both research and practice. For researchers, the results indicate that by excluding team-level commitment in research design, researchers may not fully capture the association between organizational level commitment and voice because individuals may use voice at different levels in the organization. For practitioners, the results suggest that individuals express their voice at different levels in the organization, and therefore managers should develop mechanisms and processes to capture it at both team and organizational level.

Finally, the results indicate that individuals who are highly attached to their team and have a high calculative commitment to their organization are less likely to neglect their organization. However, when individuals have a low attachment to their team, the association between calculative commitment and neglect is reversed. That is when attachment to the team is low; individuals are likely to neglect the organization. Taken together, one could infer from these results that at a high level of team commitment, individuals with a high calculative commitment do not neglect the organization by reducing work efforts or engaging in destructive behavior out of a sense of obligation and duty to their team rather than 
a desire to help the organization. Again, these results underscore the importance for researchers to focus on both foci of commitment to understand an individual's outcomes when dissatisfied with their organization. For practitioners, the results indicate that in order to avoid neglect, managers should focus more on individuals' commitment to their team rather than organizational level commitment.

\section{Limitations}

The findings of the present study must be considered in the light of a number of limitations. First, regarding sampling considerations, our sample comprised line managers and supervisors, who may differ in their behavioral intentions from lower level employees or higher-level managers. In addition, our respondents were from seven small to medium size Indian organizations based in large cities and therefore the findings may not generalize to other organizations where values and behaviors are different such as rural or semi-rural firms or multinationals operating in India. Nevertheless, within this limitation, our analysis has helped to test a number of above-discussed associations between the key independent and dependent variables in the Indian context, which makes a useful contribution to both the fields of EVLN and commitment. Second, with respect to the measurement and research design, as noted earlier, our research deals with behavioral intentions rather than actual behavior. Further, we made assumptions about the level of power distance and collectivism in India, but we suggest future research incorporates measures of these dimensions. Also, we suggest that future studies capture employees' voice systems in the organizations they study. Moreover, despite the fact that the tests that show that our instrument is valid, 
given that the data is entirely self-reported, the possibility of common method bias exists. In addition, our measure captures only one sub-dimension of calculative commitment and does not measure the "high sacrifice" sub-dimension. While these results shed light on the use of EVLN in non-western countries, much remains to be learnt about people's behaviors as a result of dissatisfaction in these countries. Lines of future research should include qualitative research, perhaps through case studies, that would help explain some of the seemingly counterintuitive results in this study.

\section{References}

Aiken, L. S. \& West, S. G. 1991. Multiple Regression: Testing and Interpreting Interactions. Newbury Park, CA: Sage.

Ajzen, I. \& Fishbein, M. 1980. Understanding Attitudes and Predicting Social Behavior (Prentice- Hall, Englewood Cliffs, New Jersey).

Ajzen, I. 1991. The Theory of Planned Behavior. Organizational Behavior \& Human Decision Processes, 50: 179-211.

Becker, T. 1992. Foci and bases of commitment: are they distinctions worth making?. Academy of Management Journal, 35(1): 232-44.

Bishop, J. W. \& Scott, K. D. 2000. An examination of organizational and team commitment in a self-directed team environment. Journal of Applied Psychology, 85: 439-450.

Bishop, J.W., Scott, K.D. \& Csino, 1997.

Bishop, J.W., Scott, K.D. \& Burroughs, S.M. 2000. Support, commitment, and employee outcomes in a team environment. Journal of Management, 26: 1113-1132. 
Boroff, K. \& Lewin, D. 1997. Loyalty, Voice, and Intent to Exit a Union Firm: A Conceptual and Empirical Analysis. Industrial and Labor Relations Review, 51: 50-63.

Brockner, J., Ackerman, G.J., Gelfand, M. J., Francesco, A. M., Chen, Z. X., Leung, K., Bierbrauer, G., Gomez, C., Kirkman, B.L. \& Shapiro, D. 2001. Culture and procedural justice: The influence of power distance on reactions to voice. Journal of Experimental Social Psychology, 37: 300315.

Budhwar, P. \& Bhatnagar, J. 2009. (Eds). Change Face of People Management in India. London: Routledge.

Budhwar, P. \& Sparrow, P. 2002. Strategic HRM through the Cultural Looking Glass: Mapping Cognitions of British and Indian HRM Managers. Organization Studies. 23 (4): 599-638.

Budhwar, P., Luthar, H. \& Bhatnagar, J. 2006. Dynamics of HRM Systems in BPOs Operating in India. Journal of Labor Research. XXVII (3): 339-360.

Budhwar, P., Woldu, H. \& Ogbonna, E. 2008. A Comparative Analysis of Cultural Value Orientations of Indians and Migrant Indians in the USA. International Journal of Cross Cultural Management, 8(1): 79-105.

Cappelli, P. \& Chauvin, K. 1991. A test of an efficiency model of grievance activity. Industrial and Labor Relations Review, 45: 3-14.

Chen, Z. X. \& Francesco, A. M. 2000. Employee demography, organizational commitment and turnover intentions in China: Do cultural differences matter? Human Relations, 53: 869-887.

Costa, C. C. 2003. Work team trust and effectiveness. Personnel Review, 32(5): 605-423. 
Earley, P.C. 1989. Social loafing and collectivism: A comparison of the United States and the People's Republic of China. Administrative Science Quarterly, 34: 565-81.

Erdogan, B. \& Liden, R. C. 2006. Collectivism as a moderator of responses to organizational justice: Implications for leader-member exchange and ingratiation. Journal of Organizational Behavior, 27: 1-17.

Farrell, D. 1983. Exit, voice, loyalty, and neglect as responses to job dissatisfaction: A multidimensional scaling study. Academy of Management Journal, 26: 596-607.

Fishbein, M. \& I. Ajzen: 1975. Belief, Attitude, Intention, and Behavior: An Introduction to Theory and Research (Addison Wesley, Reading, Mass.).

Freeman, B. R \& Medoff, L.J. 1984. What Do Unions Do? New York: Basic Books.

Gopalan, S. \& Rivera, J. 1997. Gaining a perspective on Indian value orientations: implications for expatriate managers. The International Journal of Organizational Analysis, 5/2: 156-179.

Hagedoorn, M., VanYperen, N. W., Van de Vliert, E. \& Buunk, B. P. 1999. Employees’ reactions to problematic events: A circumflex structure of five categories of responses, and the role of job satisfaction. Journal of Organizational Behavior, 20: 309-321.

Hirschman, A.O. 1970. Exit, voice and loyalty. Cambridge, MA.:Harvard University Press.

Hoffmann, E.A. 2005. Exit and Voice: Organizational Loyalty and Dispute Resolution Strategies, Social Forces, 84: 23-13 
Hofstede.G. 1991. Cultures and organizations: Software of the mind. New York: McGraw Hill.

Hui, C., Lee, C. \& Rousseau, D.M. 2004. Employment relationships in China: Do workers relate to the organization or to people?. Organization Science, 12: 232-240.

Hunt \& Morgan 1994.

Johnson, R.E., Groff, K.W. and Taing, U.M. 2009. Nature of the Interactions among Organizational Commitments: Complementary, Competitive or Synergistic?, British Journal of Management, In press.

Kaiser, H. F. 1974. An index of factorial simplicity. Psychometrika, 39: 31-36.

Kakar, S. 1971. Authority pattern and subordinate behaviors in Indian organization. Administrative Science Quarterly, 16: 298-307.

Kanter, R.M. 1968. Commitment and social organization: A study of commitment mechanisms in utopian communities. American Sociological Review, 33: 499-517.

Kidron, A. 1978. Work values and organizational commitment. Academy of Management Journal, 21: 239-48.

Kwantes, C.T. 2003. Organizational citizenship and withdrawal behaviors in the USA and India: Does commitment make a difference? International Journal of Cross Cultural Management, 3: 5-26

Lee, K., Allen, N. J., Meyer, J. P. \& Rhee, K-Y. 2001. Cross-cultural generalizability of the three-component model of organizational commitment: An application to South Korea. Applied Psychology: An International Review, 50: 596-614. 
Lewin, D. \& Boroff. E.K. 1996. The role of exit in loyalty and voice. Advances in Industrial and Labor Relations, 7: 69-96.

Lewin, D. \& Peterson, R. 1988. The modern grievance procedure in the United States. New York: Quorum Books.

Lewin, D. \& Peterson, B.R. 1999. Behavioral outcomes of grievances activity. Industrial Relations, 38: 554-576.

Luchak, A.A. 2003.What Kind of Voice Do Loyal Employees Use?. British Journal of Industrial Relations, 41: 115-134.

McGee, G. W., \& Ford, R. C. 1987. Two (or more?) dimensions of organizational commitment: Reexamination of the Affective and Continuance Commitment Scales. Journal of Applied Psychology, 72, 638-641.

Mellahi, K. \& Guermat, G. 2004. Does age matter? An empirical investigation of the effect of age on managerial values and practices in India. Journal of World Business, 39: 199-215

Meyer, P.J, Allen, J.N \& Smith, A.C. 1993. Commitment to Organizations and Occupations: Extension and Test of a Three-Component Conceptualization. Journal of Applied Psychology, 78: 538-551.

Meyer, J. P. \& Allen, N.J. 1984. Testing the "side-bet theory" of organizational commitment: Some methodological considerations. Journal of Applied Psychology, 69: 372-378.

Meyer, J. P. \& Allen, N.J. 1997. Commitment in the workplace: Theory, research, and application. Thousand Oaks, CA: Sage Publications.

Meyer, J. P., Paunonen, S., Gallatly, V., Goffin, I. R. \& Jackson, D.N. 1989. Organizational commitment and job performance: It is the nature of the commitment that counts. Journal of Applied Psychology, 74: 152-156. 
Mowday, R.T., Porter, L.W. \& Steers, R.M. 1982. Employee-organization linkages: The psychology of commitment, absenteeism, and turnover. New York: Academic Press.

Naus, F., van Iterson, A. \& Roe, R. 2007. Organizational cynicism: Extending the exit, voice, loyalty, and neglect model of employees' responses to adverse conditions in the workplace. Human Relations, 60: 683-718.

Organ, D.W. 1988. Organizational citizenship behavior. Lexington, MA: Lexington Books.

Oslon-Buchanan 1996.

Porter, L.W., Steers, R.M., Mowday, R. T. \& Boulian, P.V. 1974. Organizational commitment, job satisfaction, and turnover among psychiatric technicians. Journal of Applied Psychology, 59: 603-609.

Prestholdt, P., Lane, I. \& Mathews, R. 1987. Nurse turnover as reasoned action: development of a process model. Journal of Applied Psychology, 72: 221227.

Ramamoorthy, N. \& Flood, P. 2002. Employee attitudes and behavioral intentions: a test of the main and moderating effects of individualismcollectivism orientations. Human Relations, 55:1071-1096.

Ramamoorthy, R. \& Carroll, J.S. 1998. Individualism/Collectivism Orientations and Reactions Toward Alternative Human Resource Management Practices. Human Relations, 8: 571-588.

Ramamoorthy, R. \& Flood, P., 2004. Individualism/Collectivism, Perceived Task Interdependence and Teamwork Attitudes among Irish Blue-Collar Employees: a Test of the Main and Moderating Effects?. Human Relations, 57: 347-366. 
Ramamoorthy, R., Kulkarni, SP., Gupta. A. \& Flood, C.P. 2007. Individualismcollectivism orientation and employee attitudes: A comparison of employees from the high-technology sector in India and Ireland. Journal of International Management, 13: 187-203.

Randall, D. M. \& Gibson, M.A. 1991. Ethical Decision Making in the Medical Profession: An Application of the Theory of Planned Behavior. Journal of Business Ethics, 10: 111-122.

Redman \& Snape 2005.

Rusbult, C.E., Farrell, D., Rogers, G. \& Mainous, A.G. 1988. Impact of exchange variables on exit, voice, loyalty, and neglect: An integrative model of responses to declining job satisfaction. Academy of Management Journal, 31: 599-627.

Rusbult, C.E., Zembrodt, I.M. \& Gunn, L.K. 1982. Exit, voice, loyalty, and neglect: Responses to dissatisfaction in romantic involvements. Journal of Personality and Social Psychology, 43: 1230-1242.

Saini, D. \& Budhwar, P. 2008. Managing the Human Resource in Indian SMEs: The Role of Indigenous Realities in Organizational Working. Journal of World Business, 43: 417-434.

Shaffer et al., 2000.

Shore, L.M. \& Wayne, S.J. 1993. Commitment and employee behavior: A comparison of affective commitment and continuance commitment with perceived organizational support. Journal of Applied Psychology, 78: 774780.

Sinha, J. B. P. \& Sinha, D. 1990. Roles of social values in Indian organizations. International Journal of Psychology, 25: 705-714. 
Solinger, O.N. van Olffen, W. \& Roe, A.R. 2008. Beyond the three-component model of organizational commitment. Journal of Applied Psychology, 93: 70-83.

Sparrow, P. R. \& Budhwar, P. 1997. Competition and change: Mapping the Indian HRM recipe against worldwide patterns. Journal of World Business, 32: 224-242.

Stevens, J. P. 2002. Applied multivariate statistics for the social sciences. Lawrence Erlbaum Associates, Inc.: New York.

Tata, J. 2002. The influence of managerial accounts on employees' reactions to negative feedback. Group \& Organization Management, 27: 480-503.

Thomas, D.C. \& Pekerti, A.A. 2003. Effect of culture on situational determinants of exchange behavior in organizations: A comparison of New Zealand and Indonesia. Journal of Cross Cultural Psychology, 34: 269-281.

Triandis, H.C. 1994. Culture and social behavior. New York: McGraw-Hill.

Turnley, W. H. \& Feldman, D. C. 1999. The Impact of Psychological Contract Violations on Exit, Voice, Loyalty and Neglect. Human Relations, 52 (7): 895-922.

Vallerand, R. J., Deshaies, P., Cuerrier, J., Pelletier, L.G. \& Mongeau, C. 1992. Ajzen and Fishbein's Theory of Reasoned Action as Applied to Moral Behavior: A Confirmatory Analysis. Journal of Personality and Social Psychology, 62: 98-109.

Vandenberghe, C., Stinglhamber, F., Bentein, K. \& Delahise, T. 2001. An examination of the cross-cultural validity of a multidimensional model of commitment in Europe. Journal of Cross-Cultural Psychology, 32: 322347. 
Withey, M. J. \& Cooper, W. H. 1989. Predicting exit, voice, loyalty, and neglect. Administrative Science Quarterly, 34: 521-539.

Zhou, J. \& George, J. M. 2001. When job dissatisfaction leads to creativity:

Encouraging the expression of voice. Academy of Management Journal, 44: 682- 696. 
Table 1. Descriptive Statistics of Control Variables*

\begin{tabular}{lcc}
\hline & Mean & std. deviation \\
\hline Position (Line managers) & 0.544 & 0.499 \\
Male & 0.915 & 0.280 \\
Tenure & 6.877 & 6.783 \\
Age & 33.263 & 8.618 \\
Education & 1.925 & 0.918 \\
\hline
\end{tabular}

* All four EVLN factors and three commitment dimensions are standardized to have a mean of zero and a standard deviation of one. 
Table 2. Orthogonal rotation factor analysis for commitment items

\begin{tabular}{|c|c|c|c|c|}
\hline Items & & $\begin{array}{l}\text { Factor } \\
\text { A1 }\end{array}$ & $\begin{array}{l}\text { Factor } \\
\text { A2 }\end{array}$ & $\begin{array}{l}\text { Factor } \\
\text { A3 }\end{array}$ \\
\hline \multicolumn{5}{|c|}{ Attitudinal commitment } \\
\hline 1 & $\begin{array}{l}\text { I am very satisfied with my choice to come and work for this } \\
\text { company in comparison with other opportunities I had when I was } \\
\text { looking for a job }\end{array}$ & .082 & .834 & .128 \\
\hline 2 & I believe that company's values and my values are similar & 187 & .745 & -.029 \\
\hline 3 & I am proud to say that I am working for this company & .329 & 734 & .095 \\
\hline 4 & $\begin{array}{l}\text { This company encourages me to put the maximum effort in order to } \\
\text { be more productive }\end{array}$ & .157 & .708 & -.008 \\
\hline \multicolumn{5}{|c|}{ Calculative commitment } \\
\hline 5 & My chances of getting a job outside this company are very small & -.111 & 052 & .867 \\
\hline 6 & $\begin{array}{l}\text { I will not be able to take another job if I had to move from where I } \\
\text { live now }\end{array}$ & .122 & .067 & .878 \\
\hline \multicolumn{5}{|c|}{ Team commitment } \\
\hline 7 & I identify myself as a member of my team. & .668 & 121 & -.208 \\
\hline 8 & Being a member of my team is an important reflection of who I am & .664 & 168 & .064 \\
\hline 9 & I have strong ties with my team & .635 & .317 & .097 \\
\hline 10 & When someone criticises my team, it feels like a personal insult & .739 & .087 & .095 \\
\hline 11 & My team's success is my own success. & .709 & 164 & -.046 \\
\hline
\end{tabular}


Table 3. Orthogonal rotation factor analysis for EVLN items

\begin{tabular}{|c|c|c|c|c|c|}
\hline Items & & $\begin{array}{c}\text { Factor } \\
\text { B1 }\end{array}$ & $\begin{array}{c}\text { Factor } \\
\text { B2 }\end{array}$ & $\begin{array}{c}\text { Factor } \\
\text { B3 }\end{array}$ & $\begin{array}{c}\text { Factor } \\
\text { B4 }\end{array}$ \\
\hline \multicolumn{6}{|l|}{ Exit } \\
\hline 1 & Consider possibilities to change jobs within the company & .206 & -.008 & .688 & .116 \\
\hline 2 & Actively look for a job outside the company & .115 & -.111 & .838 & .028 \\
\hline 3 & Actively look for a job elsewhere within the same field & .169 & -.124 & .771 & .072 \\
\hline 4 & Intend to change your field of work & .156 & -.107 & .593 & .055 \\
\hline \multicolumn{6}{|c|}{ Voice } \\
\hline 5 & $\begin{array}{l}\text { Try to come to an understanding with your supervisor } \\
\text { /manager }\end{array}$ & .020 & .598 & .188 & -.298 \\
\hline 6 & $\begin{array}{l}\text { In collaboration with your supervisor/manager, try to find a } \\
\text { solution that is satisfactory to everybody }\end{array}$ & -.052 & .764 & -.299 & .036 \\
\hline 7 & $\begin{array}{l}\text { Talk with your supervisor about the problem until you reach } \\
\text { total agreement }\end{array}$ & -.158 & .797 & -.067 & .023 \\
\hline 8 & Suggest solutions to your supervisor/manager & -.141 & .631 & -.177 & .202 \\
\hline 9 & Immediately try to find a solution & -.300 & .477 & -.048 & .037 \\
\hline 10 & Try to think of different solutions to the problem & -.316 & .612 & -.068 & .073 \\
\hline \multicolumn{6}{|c|}{ Loyalty } \\
\hline 11 & Trust the organization to solve the problem without your help & .094 & .003 & .219 & .695 \\
\hline 12 & $\begin{array}{l}\text { Have faith that something like this will be taken care of by the } \\
\text { organization without you contributing to the problem-solving } \\
\text { process }\end{array}$ & .098 & -.051 & -.077 & .794 \\
\hline 13 & Assume that in the end everything will work out & .128 & .034 & -.018 & .720 \\
\hline 14 & Optimistically wait for better times & -.027 & .139 & .196 & .675 \\
\hline \multicolumn{6}{|c|}{ Neglect } \\
\hline 15 & Report sick because you do not feel like working & .759 & -.220 & .205 & .113 \\
\hline 16 & Come in late because you do not feel like working & .834 & -.198 & .207 & .034 \\
\hline 17 & Put less effort into your work than may be expected of you & .880 & -.078 & .109 & .109 \\
\hline 18 & Now and then, do not put enough effort into your work & .875 & -.149 & .147 & .070 \\
\hline 19 & $\begin{array}{l}\text { Missing out on meetings because you do not feel like } \\
\text { attending them }\end{array}$ & .820 & -.216 & .219 & .100 \\
\hline
\end{tabular}


Table 4. Partial correlation coefficients controlling for the effects of control variables*

\begin{tabular}{lcccccc}
\hline & 2 & 3 & 4 & 5 & 6 & 7 \\
\hline 1. Team commitment & $-.067\left(.452^{*}\right)$ & $-.030(.738)$ & $-.367(.000)$ & $.114(.201)$ & $-.084(.347)$ & $.038(.675)$ \\
2. Attitudinal commitment & & $-.137(.124)$ & $-.021(.815)$ & $.150(.092)$ & $-.115(.199)$ & $.177(.046)$ \\
3. Calculative commitment & & & $.152(.088)$ & $-.092(.306)$ & $.067(.455)$ & $.158(.076)$ \\
4. Neglect & & & $.034(.705)$ & $-.071(.426)$ & $-.099(.269)$ \\
5. Voice & & & & $.053(.551)$ & $-.038(.673)$ \\
6. Exit & & & & & & \\
7. Loyalty & & & & & & \\
\hline
\end{tabular}

*Figures in parentheses are the corresponding p-val 
Table 5. Results of hierarchically arranged multiple regression analysis

\begin{tabular}{|c|c|c|c|c|c|c|c|c|c|c|c|c|}
\hline Variable & & Exit & & & Voice & & & Loyalty & & & Neglect & \\
\hline & Model 1 & Model 2 & Model 3 & Model 1 & Model 2 & Model 3 & Model 1 & Model 2 & Model 3 & Model 1 & Model 2 & Model 3 \\
\hline Position & $\begin{array}{l}-0.047 \\
(0.199)\end{array}$ & $\begin{array}{l}-0.047 \\
(0.199)\end{array}$ & $\begin{array}{l}-0.035 \\
(0.193)\end{array}$ & $\begin{array}{l}0.154 \\
(0.165)\end{array}$ & $\begin{array}{c}0.154 \\
(0.164)\end{array}$ & $\begin{array}{c}0.177 \\
(0.163)\end{array}$ & $\begin{array}{l}-0.154 \\
(0.197)\end{array}$ & $\begin{array}{l}-0.154 \\
(0.198)\end{array}$ & $\begin{array}{l}-0.154 \\
(0.200)\end{array}$ & $\begin{array}{l}-0.239 \\
(0.182)\end{array}$ & $\begin{array}{l}-0.236 \\
(0.170)\end{array}$ & $\begin{array}{l}-0.235 \\
(0.170)\end{array}$ \\
\hline Male & $\begin{array}{l}-0.336 \\
(0.297)\end{array}$ & $\begin{array}{l}-0.338 \\
(0.297)\end{array}$ & $\begin{array}{l}-0.300 \\
(0.289)\end{array}$ & $\begin{array}{c}0.400 \\
(0.246)\end{array}$ & $\begin{array}{c}0.403 \\
(0.245)\end{array}$ & $\begin{array}{c}0.353 \\
(0.243)\end{array}$ & $\begin{array}{c}0.162 \\
(0.295)\end{array}$ & $\begin{array}{c}0.164 \\
(0.295)\end{array}$ & $\begin{array}{c}0.168 \\
(0.299)\end{array}$ & $\begin{array}{c}0.152 \\
(0.272)\end{array}$ & $\begin{array}{c}0.143 \\
(0.254)\end{array}$ & $\begin{array}{c}0.141 \\
(0.253)\end{array}$ \\
\hline Tenure & $\begin{array}{l}-0.005 \\
(0.019)\end{array}$ & $\begin{array}{l}-0.004 \\
(0.019)\end{array}$ & $\begin{array}{l}0.002 \\
(0.018)\end{array}$ & $\begin{array}{l}0.033^{* *} \\
(0.015)\end{array}$ & $\begin{array}{l}0.033^{* *} \\
(0.015)\end{array}$ & $\begin{array}{l}0.032 * * \\
(0.015)\end{array}$ & $\begin{array}{l}0.015 \\
(0.018)\end{array}$ & $\begin{array}{c}0.015 \\
(0.019)\end{array}$ & $\begin{array}{c}0.015 \\
(0.019)\end{array}$ & $\begin{array}{l}0.027 \\
(0.017)\end{array}$ & $\begin{array}{c}0.028 * \\
(0.016)\end{array}$ & $\begin{array}{l}0.025 \\
(0.016)\end{array}$ \\
\hline Age & $\begin{array}{l}-0.016 \\
(0.016)\end{array}$ & $\begin{array}{l}-0.012 \\
(0.016)\end{array}$ & $\begin{array}{l}-0.021 \\
(0.016)\end{array}$ & $\begin{array}{l}-0.006 \\
(0.013)\end{array}$ & $\begin{array}{l}-0.010 \\
(0.014)\end{array}$ & $\begin{array}{l}-0.009 \\
(0.014)\end{array}$ & $\begin{array}{l}-0.004 \\
(0.016)\end{array}$ & $\begin{array}{l}-0.006 \\
(0.016)\end{array}$ & $\begin{array}{l}-0.006 \\
(0.017)\end{array}$ & $\begin{array}{l}-0.047^{* *} \\
(0.015)\end{array}$ & $\begin{array}{l}-0.035 * * \\
(0.014)\end{array}$ & $\begin{array}{l}-0.030^{* *} \\
(0.014)\end{array}$ \\
\hline Education & $\begin{array}{c}0.115 \\
(0.124)\end{array}$ & $\begin{array}{c}0.128 \\
(0.125)\end{array}$ & $\begin{array}{c}0.033 \\
(0.125)\end{array}$ & $\begin{array}{c}0.097 \\
(0.103)\end{array}$ & $\begin{array}{c}0.082 \\
(0.103)\end{array}$ & $\begin{array}{l}0.115 \\
(0.105)\end{array}$ & $\begin{array}{l}-0.089 \\
(0.123)\end{array}$ & $\begin{array}{l}-0.098 \\
(0.124)\end{array}$ & $\begin{array}{l}-0.105 \\
(0.129)\end{array}$ & $\begin{array}{l}-0.115 \\
(0.114)\end{array}$ & $\begin{array}{l}-0.066 \\
(0.107)\end{array}$ & $\begin{array}{l}-0.021 \\
(0.109)\end{array}$ \\
\hline Attitudinal commitment & $\begin{array}{l}-0.106 \\
(0.089)\end{array}$ & $\begin{array}{l}-0.113 \\
(0.089)\end{array}$ & $\begin{array}{l}-0.147 \\
(0.090)\end{array}$ & $\begin{array}{c}0.116 \\
(0.074)\end{array}$ & $\begin{array}{l}0.123 * \\
(0.073)\end{array}$ & $\begin{array}{l}0.174 * * \\
(0.076)\end{array}$ & $\begin{array}{l}0.203^{* *} \\
(0.088)\end{array}$ & $\begin{array}{l}0.208^{* *} \\
(0.088)\end{array}$ & $\begin{array}{l}0.204 \text { ** } \\
(0.093)\end{array}$ & $\begin{array}{l}0.000 \\
(0.081)\end{array}$ & $\begin{array}{l}-0.024 \\
(0.076)\end{array}$ & $\begin{array}{l}-0.025 \\
(0.079)\end{array}$ \\
\hline Calculative commitment & $\begin{array}{c}0.059 \\
(0.101)\end{array}$ & $\begin{array}{c}0.055 \\
(0.101)\end{array}$ & $\begin{array}{c}0.038 \\
(0.100)\end{array}$ & $\begin{array}{l}-0.068 \\
(0.084)\end{array}$ & $\begin{array}{l}-0.063 \\
(0.084)\end{array}$ & $\begin{array}{l}-0.031 \\
(0.084)\end{array}$ & $\begin{array}{l}0.213^{* *} \\
(0.101)\end{array}$ & $\begin{array}{l}0.216 * * \\
(0.101)\end{array}$ & $\begin{array}{l}0.214 \text { ** } \\
(0.103)\end{array}$ & $\begin{array}{c}0.158^{*} \\
(0.093)\end{array}$ & $\begin{array}{l}0.142 \\
(0.087)\end{array}$ & $\begin{array}{l}0.139 \\
(0.088)\end{array}$ \\
\hline Team commitment & & $\begin{array}{l}-0.092 \\
(0.091)\end{array}$ & $\begin{array}{l}-0.119 \\
(0.089)\end{array}$ & & $\begin{array}{l}0.104 \\
(0.075)\end{array}$ & $\begin{array}{c}0.112 \\
(0.075)\end{array}$ & & $\begin{array}{l}0.059 \\
(0.090)\end{array}$ & $\begin{array}{c}0.057 \\
(0.092)\end{array}$ & & $\begin{array}{l}-0.341^{* *} \\
(0.078)\end{array}$ & $\begin{array}{l}-0.328 * * \\
(0.078)\end{array}$ \\
\hline Team $\times$ Attitudinal & & & $\begin{array}{l}0.047 \\
(0.088)\end{array}$ & & & $\begin{array}{l}-0.154^{* *} \\
(0.074)\end{array}$ & & & $\begin{array}{l}0.008 \\
(0.091)\end{array}$ & & & $\begin{array}{l}0.037 \\
(0.077)\end{array}$ \\
\hline Team $\times$ Calculative & & & $\begin{array}{l}\mathbf{0 . 2 8 6} * * \\
(0.091)\end{array}$ & & & $\begin{array}{l}-0.099 \\
(0.077)\end{array}$ & & & $\begin{array}{c}0.021 \\
(0.094)\end{array}$ & & & $\begin{array}{l}-0.135^{*} \\
(0.080)\end{array}$ \\
\hline$\Delta R^{2}$ & 0.062 & 0.008 & 0.070 & 0.131 & 0.013 & 0.036 & 0.088 & 0.003 & 0.000 & 0.132 & 0.117 & 0.020 \\
\hline 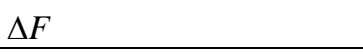 & 1.169 & 1.022 & $4.934^{* *}$ & $2.667 * *$ & 1.912 & $2.689 *$ & 1.720 & 0.427 & 0.027 & $2.699 * *$ & $19.247 * *$ & 1.692 \\
\hline
\end{tabular}




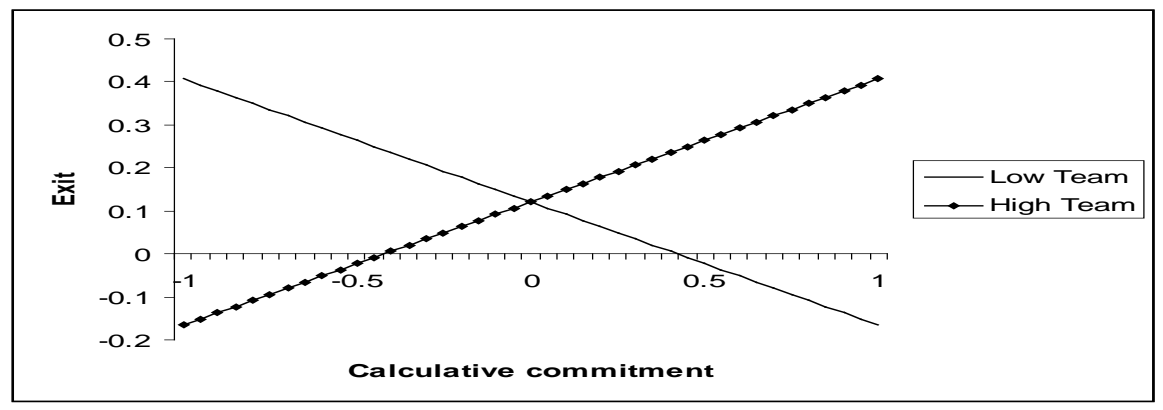

Figure 1. Calculative commitment and Exit relationship by Team commitment

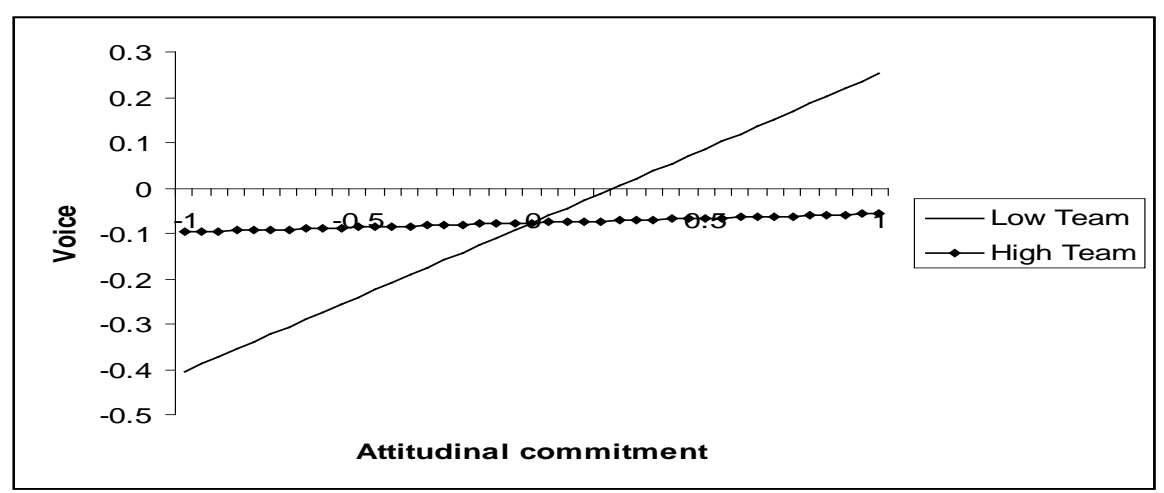

Figure 2. Attitudinal commitment and Voice relationship by Team commitment

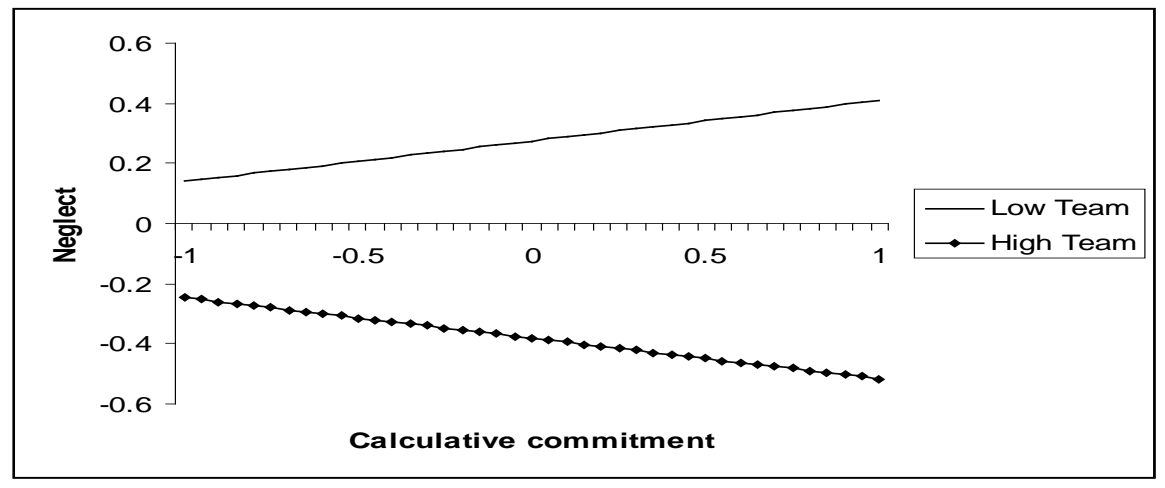

Figure 3. Calculative commitment and Neglect relationship by Team commitment 


\begin{abstract}
i Studies on EVLN have used the term "loyalty" to refer to possible action similar to exit and voice as well as a contingency factor whose presence or absence impacts individuals' choices (see Hoffmann, 2006 for a discussion). Luchak (2003) suggests that the two conceptualizations of loyalty are distinct and both should be incorporated in a study of employees' reaction to dissatisfaction with their organization. In this study, we follow Luchak's (2003) suggestion and make a distinction between loyalty as a possible response to an objectionable state of affairs and loyalty to the organization and team that influence individuals' response. We refer to the latter as organizational commitment to avoid confusion between the two concepts. Loyalty as an outcome is used to refer to employees being patient and trusting management actions.
\end{abstract}

${ }^{\text {ii }}$ We expect team level commitment to impact exit, loyalty and neglect but not voice. This is because the use of up-ward voice is not strongly associated with one's attachment to the team. 